\title{
SYNDROMES DOULOUREUX ET ANESTHÉSIE CAUDALE THÉRAPEUTIQUE*
}

\author{
Victorin Masson, M d, et Roger Matte, m D †
}

L'ANESTHÉSIE ÉPIDURALE est employée fréquemment en milieu hospitalier dans un but thérapeutique On connaît en effet les indications de ce genre d'anesthésie régionale, soit en injection simple soit en injection continue, lors de troubles vasculaires des membres inférneurs, de pancréatıte angue, de troubles rénaux, de fractures de côtes et pour soulager des douleurs intenses d'ordre médıcal, chirurg1cal ou obstétrical

Nous voulons attrrer l'attention sur la valeů de l'anesthésie caudale comme moyen thérapeutique contre les douleurs lombo-sacrées, qu'il s'agisse de lombalgie aigue, de hernie discale ou de "low back pain" chronique

On estrme que la douleur lombo-sacrée entraine un malase général plus fréquent que tout autre problème médical, sauf peut-être le rhume banal II semble qu'aux Etats-Unis, chaque année, près de \$250,000 travalleurs subissent des blessures à la région lombo-sacrée, pour lesquelles ils doivent cesser de travaller et recevoir une compensation financière Par alleurs, certains croient que 60 à 70 pour cent de la population souffre, a souffert ou scuffrira de lombalgie chronique ou aigue avec ou sans radiculalgie

Le problème est donc très important au point de vue économique, mais il pose également des problèmes au point de vue de l'hospitalisation, car ceux qui souffrent de lombalgie dorvent souvent rester au lit et subir des traitements prolongés en physiothérapie, soit par tractions soit| par manipulations, puis ils doivent parfois séjourner a l'hôpital durant une période prolongée Nous croyons que l'anesthésie caudale peut raccourcir la durée dell'hospitalisation en facilitant les traitements de physiothérapie

L'anesthésiste peut rendre service dans le trantement de la lombalgie chronique mais, le plus souvent, il n'est appelé en consultation que pour soulager un malade souffrant de lombalgie argue

1 Le traitement de la lombalgie chronique consiste en certans mouvements et exercices destinés à renforcir les muscles du dos Une caudale permet un meilleur ıelâchement musculaire et une plus grande facilté de pratıquer ces mouvements, en minimisant la douleur qui peut limiter les exercices

2 Le lumbago argu peut apparaître à la suite d'un traumatısme direcl ou indrect à la région lombo-sacrée Le malade se plainl d'une douleur intense ordnnarrement située d'un seul côté $\mathbb{A}$ l'examen, on remarque une contracture paravertébrale unilatérale ou bilatérale et une douleur intense qui est aggravée lors des mouvements

- Ce tıavasl a été presenté à la réunıon de la Societé Canadıenne des Anesthésistes, divisıon du Québec, tenue à Québec le 9 mars 1963

filôpital du Sant-Sacrement, Québec, Qué 
Le traitement recommandé est le repos absolu, la chaleur, les myorésolutifs et les massages $S_{1}$ l'on pratıque une anesthésie caudale, on provoque un relâchement marqué du spasme et un soulagement $\mathbf{1 m m e ́ d ı a t ~ d e ~ l a ~ d o u l e u r ~ i n t e n s e ~ I l ~ e s t ~ a ̀ ~}$ sıgnaler que l'amélıoiation apportée par l'anesthésie dépasse la durée de l'anesthésie Par la suite, le malade peut supporter les manipulations et les tractions qui le guérissent ou l'améliorent suffisamment pour qu'il puisse quitter l'hôpital

3 La hernie discale est surtout fréquente au niveau des quatrième et cinquième vertèbre lombaire et de la première sacrée c'est à ce niveau que se fait le plus sentur l'effet de la pesanteur

On doit se rappeler que le disque normal est constitué du noyau gélatıneux et de l'anneau fibreux le noyau gélatineux a l'aspect d'une gelée homogène A la région lombaire, 1 l est situé à l'union du tiers moyen et du tiers postérieur du disque L'anneau fibreux est composé d'une série de lamelles fibreuses disposées autour du noyau

Lors de la flexıon du rachıs, le disque se déplace vers l'arrière et prend une forme ovoide, à grosse extrémité postérieure Lors de l'extension de la colonne vertébrale, le disque se déplace vers l'avant Derrière les disques, on a le ligament vertébral commun postérieur (longitudinal) Ce dernier, étant plus épais au centre que sur les côtés, le disque a tendance à faire hernie soit à droite, soit à gauche, plutôt qu'au centre

A l'occasion d'un traumatisme, d'un mouvement brusque ou d'un effort pour soulever un poids, un noyau gélatmeux pourra s'infiltrer dans une fente d'un anneau lamelleux plus ou moins altéré, et on verra s'installer un syndrome sciatique par la compression d'une racine nerveuse, avec douleur intense el des troubles moteurs possibles

En collaboration avec le Dr Paul-Andre Lachance, chef du Service de Physiothérapie de l'Hôpital du Sant-Sacrement, le traitement des malades, dont la lombalgie et la radıculalgıe aigues nécessitent l'hôspitalısation, est habituellement le suivant

1. Repos du lit, avec planche sous le matelas

2 Manıulation et élongations vertébrales quotıdiennes et tractıons pour farre céder les spasmes musculąires

3 Ultrasonothérapie

4 Sédatufs et analgésiques au besoin

5 Une anesthésie caudale est farte en injectant $50 \mathrm{c} \mathrm{c}$ de lidocaine à 05 pour cent au moyen d'une arguille no 22 Le malade est alors placé sur le ventre durant deux heures $\mathbb{L a}$ position ventrale produit une extension du rachis, le relâchement muscularre associé à cette extensıon favorise le déplacement vers l'avant du noyau gélatineux et la réduction de la hernie discale, le cas échéant

On utilise une concentration assez faible, soit 05 pour cent dans le but de réalıser l'analgésıe et de garder la motricité

Quant à la quantité suggérée, elle peut être consıdérée par plusieurs comme étant un facteu important C'est ainsı que Moore recommande de ne pas injecter plus de 25 à $30 \mathrm{c} \mathrm{c}$ par voie caudale sous peine de vorr s'installer un niveau anesthésique élevé Cependant, lorsqu'il 'iagit de traiter des douleurs lombaures, ce même auteur recommande des doses plus fortes si après avorr injecté $25 \mathrm{c} \mathrm{c}$ 
la douleur persiste $A$ ce moment, 1 suggère d'injecter assez rapıdement 40 c.c dans le but de distendre l'espace épıdural et de briser les adhérences qui peuvent exister

Présentation de quelques cas

$1 \mathrm{MR}, 35$ ans, aucun antécédent, se présente à l'hôpital pour une dolaleur lombo-sacrée vive, ressentie en pelletant de la neige Cette douleur augmente progressivement et est exagérée par les mouvements A l'examen, on note une contracture lombaire Une caudale est pratıquée le jour de l'admission Physiothérapıe par la suite Le malade déjà guérı quitte l'hôpıtal, quatre pours plus tard

$2 \mathrm{LD}, 38$ ans, journalier, admis pour douleur au membre inférieur droit, apparues à la suite d'un effort pour soulever un poids $\mathbb{A}$ l'examen, on note ne contracture paravertébrale et un signe de Lasègue posituf à $60^{\circ}$ à droite 11 est traité en physiothérapie pendant deux semaines sans aucune améliaration Une anesthésie caudale est alors faite et on la répète quatre jours plus tard, on contınue les traitements en physiothérapie Le malade, amélioré, quitte l'hópital cinq jours plus tard

$3 \mathrm{OB}, 33$ ans, industıel, admis pour douleurs au membre inférıeur gauche, à la suite d'un effort L'examen révèle un signe de Lasègue positıf à $45^{\circ}$ à gauche Une caudale est pratiquée le lendemain de l'admission et le malade est libéré trois jours plus tard

4 A A, 54 ans, prédicateur, admıs pour douleurs lombarres chronıques depurs quelques années A l'examen, on note une contracture paravertébrale et un Lasègue positıf à droite Le malade reçoit des anesthésıes caudales, de la physiothérapie, de l'ultrasonothérapıe Au point de vue des douleurs, il est amélioré d'environ 50 pour cent après deux semaines

A la suite des caudales, nous avons observé des chutes de T A nécessitant un vasopresseur dans environ 10 pour cent des cas

Le niveau atteint, en injectant $50 \mathrm{c} \mathrm{c}$ de lidocame à 05 pour cent, est ordmairement D11 ou D12

L'anesthésie caudale nous semble supérieure aux infiltrations paravertébrales reconmandées dans certains volumes parce qu'elle a souvent un effet plus prolongé que les infiltrations qu’il faut fréquemmenl répéter pour obtenır l'effet désuré

Certains auteurs suggèrent l'injection extradurdle d'hydrocortısone avec un anesthésique local cheż les malades souffrant de hermie discale, prétextant que les stérordes auraient un effet ant1-inflammatoure bienfaisant sur les racines nerveuses comprumées

Cependant, on peut se demander si l'amélioration signalée n'est pas due simplement à l'analgésie plutôt qu'aux stérondes, l'analgésie ayant permis une meilleure traction et andé à remettre en place un disque déplacé Un spécialıste en médecine physique, $M$ le docteur Lachance, nous a recommandé de nous abstenir d'injecter de l'hydrocortısone, car 11 semble que cela puisse entraîner le développement d'une radiculite

Ainsı, l'anesthésıe caudale nous semble utile pour soulager la douleur et les spasmes muscularres qui l'accompagnent Elle permet de manipuler plus précocement les malades souffrant de "low back pain" et raccourcit la durée du traitement 
Ce traitement conservateur nous a paru tres utile chez les malades souffrant de lombalgıe argue et de radiculalgıe récente Il y a aussı amélioration chez les malades ayant une lombalgıe chronıque $\mathrm{Pa}$ allleurs, des malades améliorés par la caudale au point de vue douleurs ont dû, par la suite, subir une discoidectomie

\section{RÉsumé}

Après un rappel anatomıque du disque intervertébral, nous avons décrit l'injectıon par voie caudale de lidocaine à 05 pour cent, après laquelle le malade demeure en position ventrale durant deux heures, pour favoriser l'extension de la colonne lombaire

Cette technique, associée à la physiothérapie, nous a paru très utıle dans le traitement des malades souffrant de lombalgie argue ou chronique

\section{SUMMAFiY}

The sedentary habits of our population are one cause of the increase in the frequency of occurrence of lumbar pains The lumbosacral region is of ten required to make a considerable effort for which it is not pi epared

Sixty to seventy per cent of adults suffer, have suffered, or will suffer trom chronic lumbar pain or acute lumbar pain with or without root neuralgia

The anaesthetist should be able to render a service in the treatment of simple lumbar pains, but he is most often consulted for the treatment of patients suffering from acute lumbar pain accompanied by root neuralgia, usually due to a herniated intervertebral disk

Anatomically, it should be recalled that the normal disk is composed of two parts the nucleus pulposus and the annulus fibrosis The nucleus pulposus has the consistency of a homogeneous jelly In the lumbar region it is situated in the lower and posterior part of the disk The lamellar ring or annulus fibrosis is composed of a series of fibrous lamelli disposed around the nucleus

During movements of the spine this nucleus is easily displaced and deformed During flexion the nucleus is displaced posierioly and takes an ovord form with the large end posteriorly In extension the opposite occurs, the nucleus being displaced forward

In the event of trauma, a sudden movernent or an effort to lift a weight, the nucleus pulposus is able to infiltrate through a gap in the lamellar ting which is more or less altered Nerve root compression and intense pain may result The roots of L5 and S1 are most often involved, with pain in the distribution of the sciatic nerve

The treatment of patients with lumbar pain and acute radiculitis necessitating hospitalization is usually as follows at the l'Hôpital du Saint-Sacrement

1 Bed rest with a board under the mattress

2 Ant1-inflammatory treatment (Tandearl, Phenylbutazone)

3 Daily vertebral traction with enough force to relieve the muscular spasms

4 Vertebral manipulations

5 Ultrasonic therapy and stimulation 
6 Sedatives and narcotics for patients with severe pain

7 Caudal anaesthesia with $50 \mathrm{cc}$ of 05 per cent lidocaine

We leave the patient in the prone position for two hours after injection and repeat the caudal anaesthesia on two or three days if necessary

Caudal anaesthesia seems useful to us for the following reasons

1 To relieve the pain and muscular spasms which accompany it

2 A volume of $45 \mathrm{c} \mathrm{c}$ injected with pressure, after a preliminary dose of $5 \mathrm{c} \mathrm{c}$ has been injected to ensure that one is properly in the epidural space, may break down certain adhesions and free the nerve roots

3 The ventral or prone position tends to extend the spine The muscular relaxation associated with this extension favours the displacement of the nucleus polposus anteriorly and the reduction of the herniation of the disk

This conservative treatment appears useful to $u$, in the case of those patients having an acute lumbar pain with recent radiculitis In the case of patients who have suffered for many years, they have been relieved sufficiently or are subjected in the first instance to a discectomy

\section{BIBLIOGRAPHIE}

1 Goebert, $\mathbb{H}$ W et al Panful Radiculopathy Treated with Epidural Injections of Procaine and Hydrocortisone Acetate Anesth \& Analg Current Researches (Jan 1961)

2 Finneson, X X Diagnosis and Management of Pain Syndromes

3 Moore, $\mathbb{D}$ C Regional Block

4 Trahan, $M$ Continuous Epldural Anaesthesia in Multuple Fractures of the Rubs Canad Anaesth Soc J 8512 (1961) 